Media Industries $5.2(2018)$

\title{
Entertaining Africans: Creative Innovation in the (Internet) Television Space
}

\author{
Lindiwe Dovey ${ }^{1}$
}

SOAS UNIVERSITY OF LONDON

LD18 [AT] soas.ac.uk

\begin{abstract}
In the growing scholarly literature on internet television, Africa is mentioned tangentially, if at all. This article attempts to rectify this by offering one of the first studies of Africa-based and Africa-focused internet television and video on demand (VOD) for domestic and diasporan African audiences. It begins by giving a brief overview of screen and television infrastructure across Africa before moving on to describe the landscape of internet television in Africa, focusing on six core competitive factors: content, internet connectivity, data costs, payment options, security, and multimedia convergence. Finally, it identifies and briefly analyzes the potentially most popular Africa-based and Africa-focused internet television and VOD platforms. The article draws on original interviews conducted with key players at some of the most important Africa-based and African-focused internet television and VOD platforms and with other African media scholars and filmmakers who have expertise in different regions of the continent (and specifically Senegal, Ethiopia, Angola, Rwanda, and Kenya).
\end{abstract}

Keywords: African Internet Television, African VOD, Mobile Television, Nollywood, Digital Turn

\section{Introduction}

Despite great heterogeneity, the vast continent of Africa and the diverse people of its countries and in its diasporas have often been represented through the most reductive, essentializing, and denigrating paradigms - a process that Nigerian writer Chimamanda Ngozi Adichie has referred to as "the danger of a single story." " One of the most dangerous of these paradigms is the developmentalist one, which shoehorns Africa into a western, capitalist 
teleological framework that overlooks and denies Africa's production of and participation in forms of leisure, pleasure, and entertainment. ${ }^{3}$ The prevalence of Western development and aid organizations throughout Africa means that Africans have frequently been encouraged to internalize and perpetuate this paradigm within their own work and theorizing. ${ }^{4}$ Within African screen media studies, much recent attention has been devoted to how Nollywoodthe southern Nigerian video-film industry, which originated in 1992 partly out of television practices ${ }^{5}$-has helped to engender a turn away from what certain scholars call "developmentality" ${ }^{\prime 6}$ toward recognizing the value and popularity of home-grown entertainment. ${ }^{7}$ This scholarship builds on vital points made in Charles Okigbo's foundational research on television in Africa, in which, he argues, "Many Africans make a clear distinction between serious use of the traditional/modern mass media as instructional channels and their use for enjoyment. Television use is more of the latter." ${ }^{8}$

Very little scholarly attention has been given to how African television as a whole (and not just Nollywood) has been "primarily an entertainment medium"9 while inevitably allowing for "the common exchange of information and sharing of values." 10 This is remarkable when we consider that

television has become the primary form for consuming electronically recorded fictional narratives around Africa. In any case, when asked what "films" they have watched recently, many Africans are more likely to refer to filmed narratives that they have watched on television. ${ }^{11}$

Even less scholarly attention has been given to how contemporary screen media companies that focus on broadcasting and/or distributing African-made audiovisual content have been trying to capitalize on the entertainment potential of television brought about by new technology and, in particular, the internet. As Adejunmobi astutely points out, "Many of the online platforms for African films that have come into existence in the past few years likewise allude to the primary site of spectatorship in Africa by adding the word TV to their name."12

In this article, I use the framework of cultural geographies of access to critique mainstream theorizing of internet television that ignores how differences across regions significantly change how internet television operates and how we are able to think about it. While I explore the work of several screen media companies that target pan-African markets within and beyond Africa, ${ }^{13}$ my main focus is the technological constraints that have confronted these companies on the African continent itself and how these companies have been experimenting with creative solutions to these obstacles. These creative solutions include the following: the development of mobile phone apps and short-form content designed for "supersmall" screens, partnerships not only with telecommunications companies but also between television providers that have historically serviced different parts of Africa, and an investment in both nonlinear and linear television to be able to bring content to as many markets as possible.

This article attempts to adopt a media industries approach to African screen media. ${ }^{14}$ There have been several excellent articles that examine the relationship between Nollywood and the internet, but their focus tends to be on the audience rather than the industry players. ${ }^{15}$ There is a growing body of work on social media use in Africa, but, again, the focus is often on development and education to the exclusion of entertainment. ${ }^{16}$ In defining television as 
"primarily an entertainment medium" in this article, I do not intend to deny television's equally important role as a transmitter of news and current affairs or of instruction. Indeed, it is often difficult to separate what constitutes "entertainment" or "education" as they frequently overlap and depend to a great deal on how screen media texts are interpreted by distinct consumers. Nollywood filmmakers, for example, often refer to their films as a form of "edutainment." However, in that I am attempting in this article to think through how television is changing globally due to the internet, I am especially concerned with new theorizing of television ${ }^{17}$ that emphasizes its "on-demand" entertainment value; this definition puts television not so much "in competition" with other forms of screen media as with all potential forms of leisure and entertainment. My focus is thus on innovations within companies concerning genres of television such as drama series, movies, and music videos rather than newscasts and current affairs shows. Sport is, of course, one of the most popular genres of television entertainment, but it is beyond the scope of my current research.

\section{Methodology}

Explaining the methodology that I have used in conducting this research also requires that I tell the story of how I became interested in the topic in the first place. It was while I was conducting research in different parts of Africa for my previous book, Curating Africa in the Age of Film Festivals (2015), that I became aware of a rise not only in live distribution and exhibition of African cinema through an increasing number of film festivals but also in online distribution of African films and television series through an increasing number of over-thetop (OTT) internet platforms. In 2010, AfricaFilms.tv-a video on-demand (VOD) platform focused on independent African cinema as well as popular television series-was created by Enrico Chiesa, an Italian living in Senegal, with funding from the ACP (Africa, Caribbean and Pacific) European Union fund. In 2012, Buni.tv-a VOD platform for high-quality African film and television content-was launched in Kenya by French entrepreneur Marie Lora-Mungai with funding from the Ford Foundation. After conversations and interviews with Chiesa and Lora-Mungai in 2014, and after seeing the geographical limitations of live film festivals during my research, I realized the online possibilities for businesses wanting to scale themselves to bring African-made content to much larger, more dispersed audiences.

I started by trying to identify some of the key African screen media companies with the idea of exploring their online distribution strategies and came up with the following: iROKO, today a multimedia company that licenses, distributes, streams, and produces Nollywood content and which offers both a subscription video on-demand (SVOD) service iROKO.tv and an Android app service (launched in 2011 from the United Kingdom by Nigerian entrepreneur Jason Njoku); Afrinolly, an African movie database and marketplace (launched in 2011 from Nigeria by Nigerian entrepreneur Chike Maduegbuna); Showmax, an SVOD service offering African and non-African content in thirty-six African countries as well as in several non-African countries such as Poland and the United Kingdom (launched in 2015 from South Africa as a brand of multimedia company Naspers-arguably the largest and wealthiest media corporation based in Africa and the owner also of South African pay-TV channel M-Net and digital satellite company DStv); Okiki, a desktop and mobile application that aims to make African movie streaming social 
(launched in 2016 from the United Kingdom by Nigerian entrepreneurs Femi and Bayo Dada); Kwesé, a multiplatform media company offering free-to-air, pay, and online television (through Kwesé Play) in fourteen African countries (launched in 2017 in Mauritius as a brand of Econet Media Limited, founded by Zimbabwean entrepreneur Strive Masiyiwa); and Afrostream, an SVOD service which operated from 2014 to 2017 and that focused on bringing the best of black films and television series from around the world to global audiences (launched in 2014 from France by Cameroonian entrepreneur Tonjé Bakang).

While almost all of these companies market themselves as pan-African to some extent, distinctions in how they define "Africa" can be seen in terms of how they position themselves in relation to race, class, taste, and language. iROKO, Kwesé, and Afrostream have all clearly targeted and marketed themselves to a transnational, pan-African, black-identifying, largely middle-class audience wanting to watch similarly classified content. However, if we dig a little deeper we can see differences in the kind of content and audiences each of these platforms orients itself around. iROKO focuses on the transnational popularity of Nollywood films and series; Kwesé appears to be focusing on combining global mainstream content (as an official partner of Netflix) with its own hyperlocal content; and Afrostream, while it was in operation, focused on black content from around the world. Showmax defines "Africa" quite differently; it has a large catalog of Afrikaans language content as well as content in indigenous South African languages, and it is also investing a great deal in licensing and commissioning content in new contexts, such as Kenya. ${ }^{18}$

In August and September 2016, I conducted five interviews with people in senior positions at some of these companies, as well as other important African media companies: Bob van Dijk, the CEO of Naspers, which owns Showmax; Yolisa Phahle, CEO of M-Net (another brand of Naspers); Jessica Hope, Head of Communications at iROKO; Bobola Oniwura, cofounder and creative director of Afrinolly; and Bayo Dada, cofounder of Okiki. All of these interviews were conducted in a semi-structured way via Skype, with a duration of between thirty minutes and one hour, except for the interview with Bayo Dada, which was conducted over email. I presented my initial findings from this research at the African Studies Association of the UK conference in September 2016. Since then, my methodology has involved trying to track movements in the online distribution of African audiovisual content through the trade press and secondary literature; through conversations and interviews with African filmmakers, media scholars, and experts who work on very different regions (such as Kenya, Rwanda, Senegal, Angola, and Ethiopia); and by conducting further interviews with people who were also identified as key players in the industry: Chris Savides, the Head of Showmax in Africa (interviewed by e-mail in January 2018); Tonjé Bakang, the founder of Afrostream (via an hour-long, semi-structured Skype interview in March 2018, with Jorge Cohen); and Dorothy Ghettuba, cofounder of Spielworks Media in Nairobi (via an hour-long, semi-structured Skype interview in May 2018). This article does not present a specific case study or longitudinal study, then, but draws on different interviews over time to try to problematize the normative nature of some of the current theorizing of internet television, most of which focuses on Euro-American contexts. North American scholars of internet television who focus on that context acknowledge that there "are unquestionably aspects relevant in other national contexts"19; it is time that we start incorporating these contexts into our theorizing to provide a more global picture of internet television. 


\section{Bridging or Reinforcing the Domestic/ Diasporan Divide? The Constraints and Solutions to Internet Television in Continental Africa}

As television becomes a streaming service, delivered over the internet rather than through the airwaves, it becomes location-aware (and location-blind) in new ways. ... Approaching the internet as a localised and unevenly available set of cultural experiences-as opposed to a global, universal superhighway-reminds us that the internet, like television, is always locally configured as well as globally networked. ${ }^{20}$

Amid the burgeoning scholarship on internet television, ${ }^{21}$ Ramon Lobato and James Meese's open-access book Geoblocking and Global Video Culture (2015) is unusual in not only arguing for the importance of including perspectives from beyond Euro-America but also actually including and foregrounding such perspectives (encompassing case studies from countries as diverse as China, Turkey, Malaysia, Brazil, Iran, and Cuba). Indeed, such perspectives are vital for challenging universalizing theory that takes as its reference points only wealthy contexts in Europe and North America. As I will show, experiences of internet television for the majority of Africans on the continent are vastly different from those in the wealthy West, including for members of the African diaspora who have access to desktops, laptops, and high-speed internet. Chris Savides, Africa Head of Naspers's SVOD platform Showmax, suggests that radical changes are afoot with the development of new technology such as Chromecast, through which one can use a smartphone as the engine to power lean-back viewing on a TV ${ }^{22}$ but it is difficult to predict when this technology might become affordable for mass markets in under-resourced contexts.

Whereas platform mobility and watching television on multiple devices are frequently assumed in Western scholarship on internet television, my interviews have revealed a common emphasis on the technological constraints to providing the majority of Africa-based audiences with access to internet television. The main issues concern the difficulty of accessing fixed line broadband, low bandwidth, high data costs, lack of online payment options, and an inability or unwillingness to pay for content. As CEO of Naspers, Bob van Dijk, sums up in terms of the issues with broadband and mobile data costs in Africa:

If you look at the number of people who have fixed line broadband that is good enough for streaming to the big screen it's a very small subset of people on the [African] continent, so I don't believe that will be the way people consume it. It will all be on smartphones in the end. But even there you have massive connectivity issues. ... if you want uncapped mobile broadband in many markets it costs one person's annual salary on average and so it's for the very few.... And the very few tends to be expats or the extremely well off who are probably not your consumers of local content.... So we probably have to work with mobile operators to make it accessible to people. ${ }^{23}$

In short, the kinds of technological issues and challenges being confronted in Africa are vastly different from those in the United States. In relation to the latter context, Amanda Lotz says, "Viewing device is irrelevant to this discussion. Internet protocol distribution now commonly delivers television to living room sets, mobile devices, as well as computers." ${ }^{24}$ In 
contrast, viewing device is absolutely not irrelevant when it comes to less affluent contexts. Traditional television statistics in Africa are dwarfed by recent statistics emerging around smartphone ownership and mobile internet subscriptions in the region. While it is estimated that there were 58.3 million television sets in sub-Saharan Africa in 2016, ${ }^{25}$ there were an estimated 181 million unique mobile internet subscribers in the same year ${ }^{26}$ for a region of approximately one billion people. Huge growth in mobile internet subscriptions is predicted in the next four years, particularly in Nigeria, Kenya, and South Africa. ${ }^{27}$ In Africa, the nearterm future of internet television will thus be mobile and, in theoretical discussions, the focus will need to be on the mobility of human viewers rather than, as in the discourses about digital delivery in the United States and Europe, on the mobility of media from one platform to another. ${ }^{28}$ Furthermore, the focus will need to be not simply on what Alessandro Jedlowski has called the "small screen cinema" format ${ }^{29}$ or what Glen Creeber has called the "small screen aesthetics" associated with television and internet as exhibition platform, ${ }^{30}$ but on what we might call the "supersmall" screen of the smartphone.

In contrast, many Africans living outside of the continent, for example, in the United States, Canada, and the United Kingdom, are easily able to access fixed line broadband with high bandwidth, which allows them to stream content on television screens, desktops, and laptops. As van Dijk says

as Jason [Njoku] would also tell you, it's often much easier to find people in the diaspora to be customers [of online African content] because they do have that connectivity and don't have to worry about marginal costs. And [they] are somewhat deprived of that content that they want to watch from where they are from. ${ }^{31}$

In other words, for diasporan audiences, African-focused SVOD platforms help to bridge the distance from the continent in terms of bringing Africa-based content closer; however, that same online African content is often unavailable to Africa-based audiences. Jessica Hope, Head of Communications for iROKO, confirmed in her interview with me that the majority of the users of their SVOD platform are based in the diaspora and she told me that iROKO had to entirely change its strategy when it tried to move into Africa-based markets in 2015 from its base in the United Kingdom:

The audience [in Africa] was just like, we can't access the content, it is very difficult to watch uninterrupted, long-form content. Not just the bandwidth problem but also the expense of data especially in somewhere like Nigeria, it was just extortionate. So our audiences just couldn't afford to watch the content and they didn't have the capability of streaming content without interruption so that led to the decision to look at how people consume content which is most likely on their mobile. Android is the most frequently used operating system in Africa. So the company switched off their streaming platform [in Africa] and developed an Android app. ${ }^{32}$

iROKO's Android app actually eliminated streaming altogether and offered instead downloads of films, re-encoded at 50-100 megabytes. Still, companies such as iROKO offering Android apps within Africa face the challenges of low data storage on Android smartphones, as well as unreliable electricity for charging phone batteries. ${ }^{33}$ Nevertheless, going mobileonly or app-only appears to be the only way that such companies are currently surviving in Africa-based markets. Bobola Oniwura from Afrinolly, an Africa-based African film database 
and marketplace, emphasizes, "We are strictly African entertainment in the pocket, all films on mobile only." ${ }^{34}$ He suggested that going app-only was also a way to circumvent piracy, but other people I have interviewed have contradicted this, stating that apps can also be pirated. Going mobile-only thus appears primarily to be a strategy in relation to most Africans' lack of access to desktop and laptop computers on the continent. And, without consistent, highspeed internet, the ability to "stream" cannot be taken for granted.

For Tonjé Bakang, trying to move his streaming VOD platform Afrostream, launched in Paris in 2014, into twenty-four African countries was possibly one of the factors that led to the demise of the platform altogether as he underestimated the different priorities of Africabased audiences. As he told Angolan media scholar Jorge Cohen and myself in an interview,

The African diaspora in Europe was the biggest market for us. I'd say around 80\% were in Europe. ... My aim was to provide relevant content for black people all over the planet. So having a good start in Europe with the African diaspora and people who love African and black content was great for me. What is happening in Africa is the internet and its priorities. So it's not like you launch this luxury product with movies and series, it's not like people will stop eating to watch this service! You put money into entertainment when you have solved most of the issues in your life and then you will buy a premier movie online. ${ }^{35}$

For a company such as Afrostream, which focused on acquiring and streaming long-form content such as feature-length movies and mainstream television series, Bakang acknowledges that it was very early to enter a context such as sub-Saharan Africa, where the majority of people can only access the internet via their mobile phones. As Bakang notes, "When I'm on the [African] continent I see a lot of people watching content on their phones but it is short-form content." ${ }^{\text {I6 }}$ Indeed, my interviews with media scholars who study different contexts in Africa confirmed that what the majority of Africa-based audiences tend to watch on their phones are free short clips, mostly from YouTube, which-according to the Sandvine network-level data on Africa-is the most popular internet site in Africa by traffic volume. ${ }^{37}$ Jorge Cohen has identified at least thirty dedicated Nollywood YouTube channels, with more than fifty thousand videos, five million channel subscriptions, and two billion total views, ${ }^{38}$ although it is difficult to know how many of these channels, subscriptions, and views are coming from the continent. Such channels are monetizing themselves through advertising and have accordingly been hit hard by the recent advertising boycott of Google. ${ }^{39}$

Companies such as Afrinolly have responded to these challenges not only by going "strictly mobile" but also by prioritizing the development of short-form content through a short film competition that ran from 2013 to 2014. As Bobola Oniwura told me,

[Through the Afrinolly short film competition] we wanted to ignite the creation of short film content. We realised if people are going to be watching more short form contents on mobile there must be those who are producing that content. ${ }^{40}$

Other reports and interviews seem to confirm that there is growing investment in the creation of short form, as well as the repurposing of long-form content to make it conform to the growing need and demand for short-form content for mobile phones. Launched in Malaysia in 2014, SVOD platform iflix recently recognized that operating in emerging markets demands a "new model" from it, one that includes-among other things-the 
development of original, premium, short-form content through iflix's own short-form content studio, Studio 215. Studio 215 has the ambition of producing two thousand short-form pieces by the end of 2018. ${ }^{41}$ Similarly, Kenyan media entrepreneur Dorothy Ghettuba told me in an interview that her company, Spielworks Media, is "repurposing" their long-form drama series into "bite size pieces" because their research shows that "more people are consuming [content] on the mobile phone" and that the "sweet spot" in terms of viewing drama on phones is six minutes. ${ }^{42}$

As iflix CEO Mark Britt acknowledges, "When we began iflix, we naively believed that the Western entertainment model could easily succeed in emerging markets ... we [now] have a much deeper understanding of the localization requirements, and infrastructure, payments and authentication issues within our territories." ${ }^{33}$ Indeed, another problem that besets the shift to online television viewing in Africa is the lack of online payment options. As Bobola Oniwura says,

there are very few Africans who have banked, and there are very few Africans who have banked with credit or debit cards. So if you expect for Africans to pay for content or pay for your goods via credit or debit card, you're only going to be dealing with a minority of the market. ${ }^{44}$

The race to dominate the African internet television market has a great deal to do-as van Dijk suggests above-with how quickly different companies have been able to integrate their services with those of telecommunications companies, offering consumers the option of paying for movies with their mobile phone airtime. Afrinolly has, for example, integrated with MTN in Nigeria, with four telecommunications companies in South Africa (including Vodacom), and with Safaricom and Ntel in Kenya. ${ }^{45}$ Chris Savides, the Head of Showmax Africa, was chosen for the role because of his previous experience of bringing PayPal to South Africa and Kenya through a position at First National Bank. As he acknowledged in our interview, "My particular skills from the banking industry in payments and partnerships were what brought me to this role-we knew that localization would be a key success factor and that credit card payment options alone would not be enough." ${ }^{46}$ Recognizing this need for localization, Netflix has recently teamed up with Kwesé, which has helped it to offer its service in South Africa in the local currency in exchange for Kwesé offering Netflix as one of its channels. Success depends not simply on the availability of the technology but establishing consumer trust in the technology; even when online payment options are available, many reject using them out of fear of online fraud. Jason Njoku, CEO and founder of iROKO, also emphasizes that "whilst a huge percentage of the population has a smartphone, outside of using it for calls, Facebook and WhatsApp, there's little understanding of all the things you can actually do with an Android phone. ${ }^{" 77}$ This issue is not limited to Africa; as Henry Jenkins notes, there are people like himself everywhere who just want a phone to make calls. ${ }^{48}$

If people cannot pay easily, then the issue of unauthorized access arises. As Ravi Sundaram and Ramon Lobato have shown, "piratic infrastructures" tend to develop where a lack of access to media means that so-called "piracy" becomes the only option for consumers. ${ }^{49}$ Furthermore, we have to ask what will make Africa-based audiences pay for online content when they can access a great deal of content for free through YouTube and when there is also pirated content available very cheaply on street corners, such as on USB sticks sold for US\$2US\$ $4 ?^{50}$ Perhaps this is where pay television statistics in Africa can be helpful; there were an 
estimated twenty-four million pay television subscribers in sub-Saharan Africa in $2016 .^{51}$ Is this audience, able and willing to pay for content and more likely to have the resources to own a desktop and laptop, the future market for SVOD platforms in Africa? The problem is not limited to resources, however. Reflecting on the failure of Afrostream, Tonje Bakang says, "One of the big questions we can ask is why the African community, the diaspora, the people who love black movies and African movies, never support it. Not just by tweeting but by subscribing. ${ }^{" 52}$ With a thirty-five thousand-subscriber base at its height, Afrostream was still not able to attract sufficient subscribers to be able to pay the high annual license fees for content. $^{53}$ This raises the question, how will SVOD platforms survive in the long run?

\section{Beyond "Competition" in the African (Internet) Television Marketplace: New Business and Regional Alliances}

New entrants and anything that raises the profile of existing services are good things for us. One of our biggest challenges has been customer education-what is this internet TV thing? Why should I want it? How do I get it? We welcome anyone else entering the market and helping with that heavy lifting.... [O]ur experience is that this isn't a binary thing in that consumers happily subscribe to more than one service at a time, so the mere addition of more options does not equate to a smaller opportunity for Showmax." 54

While Chris Savides's reference above to a collaborative rather than competitive ethos among African (internet) television providers is rather too idealized, it is interesting to note that the terrain can indeed be characterized by dynamic and sometimes unlikely partnerships. Not only are the key players teaming up with telecommunications companies, but they are also increasingly teaming up with one another to offer specific deals or packages to consumers. These partnerships are strategic not only at the technological and economic level but also in terms of how certain companies want to redefine themselves in relationship to particular definitions of "Africa." I will look briefly here at two of these partnerships: Showmax's recent partnership with Zuku, an East African company focused on residential fiber broadband services and cable television, and iROKO's recent partnership with Canal+, the French cable television channel which has been operating since 1984. Of particular note here is that these partnerships not only create new regional alliances but also involve a cross-fertilization of linear and nonlinear television models, which will lead me into my final argument.

\section{Showmax Meets Zuku}

When I asked Showmax-which launched in 2015 and has quickly expanded into thirty-six African countries-which countries they would not be entering and why, I was told,

We are not going north of the Sahara and for two reasons: French speaking and Arabic speaking. For linear TV [M-Net, DStv] we have only operated in sub-Saharan Africa. Our audience understanding really stops there. The francophone audiences we are much less familiar with. And we need an understanding of what people like and want to consume. ${ }^{55}$ 
Out of these thirty-six countries into which Showmax has expanded, Kenya is the country that has been prioritized, partly because of its Anglophone status and partly because Naspers's pay-TV channel M-Net has production studios there. Showmax has hired a local Kenyan team to handle content acquisition and marketing, and African content is indeed being licensed-for example, the television series This Is It (2016-), which stars Kenyan actor Nick Mutuma although it was made by young Nigerian filmmaker Omolola Adeleke. Showmax also has ambitions to commission and produce Kenyan content, and Naspers in general has a strong reputation when it comes to corporate social investment and putting money into the development of talent. ${ }^{56}$ However, even in Kenya Showmax has been struggling to establish a subscriber base; a small survey of media-makers in Nairobi that Kenyan media entrepreneur and filmmaker Judy Kibinge undertook revealed a lack of knowledge about and/or engagement with Showmax. ${ }^{57}$

Within such a context of low uptake, it is not surprising that Showmax has recently formed a partnership with East African company Zuku to offer a new service called "Zuku Fiber plus Showmax." ${ }^{58}$ Kibinge points out that Zuku's success has come through offering internet with cable television as an added bonus; she says that Africa-based consumers want the internet first and foremost because they can then access an infinite amount of free content. ${ }^{59}$ However, Zuku has been facing competition from broadband-only providers (such as SEACOM) as well as from pay-TV (such as Multichoice's DStv) and on-demand companies (such as Netflix). ${ }^{60}$ The new deal with Showmax is presumably attractive to Zuku because it allows them to maintain their unique selling point of offering both internet and content while expanding their catalog of local content through Showmax. The deal is vital, in turn, to Showmax because, as noted above, they appear to have been struggling to break into Kenya.

\section{iROKO Meets Canal+}

While Showmax has been more tentative when it comes to the crossing of linguistic boundaries in Africa, iROKO is challenging old, colonial-era linguistic blocs through its partnerships, bringing Nollywood to new audiences. With the advent of Nollywood in 1992, linear television channels have rushed to incorporate such content, which is popular across Africa and its diverse diasporas. ${ }^{61}$ For example, pay-TV channel MNet's Africa Magic bouquet focuses on Nollywood, and ROK Studios, the production branch of iROKO, has recently partnered with DStv to create a Nollywood channel that will be available in fifty-two African countries. ${ }^{62}$ But what is perhaps most interesting in the current environment is that the thirst for Nollywood films and series across the continent seems to be eroding the historical divides between Anglophone and Francophone Africa, stimulating partnerships among key players working across traditional and internet television.

In particular, iROKO has been working with the company that has historically dominated television provision in Francophone Africa-French cable television company Canal+-to dub Nollywood films into French and bring them to Francophone African markets in a variety of ways. In December 2015, iROKO and Canal+ announced a multimillion euro deal through which they plan to bring popular, Nollywood films to French-speaking African markets through a mobile Android app. ${ }^{63}$ The benefit to Canal+ was in being able to enter the Nollywood VOD market, pioneered by iROKO, as acknowledged by Canal+ Overseas 
president Jacques du Puy when he said, "Now that Canal+ is close to having two million payTV households in Africa, our ambition is to widen our audience to those whose mobile is the main entertainment device." And, the advantage for iROKO was, according to Jason Njoku, the fact that "Canal+ has over 20 years' experience of delivering content to Francophone Africa." 64

Such partnerships with other, well-established companies are vital to sustain iROKO's existence, particularly because it is very difficult for a stand-alone VOD platform to survive. As Jessica Hope emphasized in our interview, the actual production of Nollywood content has become central to iROKO's survival because "iROKO almost priced itself out of the market by paying for licence fees. It's very difficult to recoup these costs just through iROKO.tv so that's why we had to look to producing content and to other distribution deals." ${ }^{65}$ iROKO's success could thus be said to have emerged through its disciplined, close focus on licensing, distributing, and producing only Nollywood content, for Nollywood fans across the world. Indeed, as Hope notes,

our audience mainly wants to watch Nollywood so our focus has been very much on Nollywood. A couple of years ago we put on a film from Kenya or somewhere else, and our fans just hated it. It's a really niche Nollywood audience. ${ }^{66}$

In contrast, Afrostream's pitch-"We will tell you stories that will empower you, stories with black people, stories from the African continent, the States, from the African diaspora"-was perhaps too broad. Indeed, Bakang said part of the downfall of the company was the huge cost of licensing fees, and he has now moved into content production. ${ }^{67}$ iROKO has managed to keep building and expanding its operations because of its relentless focus on being the first port-of-call for Nollywood films-whether that be original content made by iROKO or Nollywood films exclusively licensed by iROKO and made available through its SVOD service, its Android app, or aggregated for other companies (e.g., British Airways, which iROKO provides with Nollywood movies). As Hope emphasizes, however, funding-such as the investment from Canal+-has been crucial to iROKO's success: "iROKO is the most well-funded [Nollywood] VOD out there so it had the buying power through VC funding." ${ }^{6}$ While exploring the uptake of Nollywood films dubbed into French and other languages is beyond the scope of this article, it will be fascinating in future to analyze whether iROKO's partnership with Canal+ succeeds in creating new markets for Nollywood.

\section{Online Video Did Not Kill the Linear Star: Old and New Media Convergence in the African Television Space}

As is evident from the partnerships described above, both legacy and internet television companies see the necessity of working together, particularly in emerging markets such as those in Africa, where streaming long-form content is currently very difficult and accessible only to a privileged minority. As Bob van Dijk notes, 
Linear TV has much more financial strength. Showmax is a significantly loss-making service at the moment.... Linear TV has a number of key strengths-around sports, show formats, the newest and latest, and I think that will continue to exist. ${ }^{69}$

Indeed, although Showmax emerged out of the behemoth Naspers as a stand-alone SVOD platform, it has recently been incorporated into MultiChoice's DStv's digital media unit (also owned by Naspers). This indicates that the company does not currently see Showmax as financially viable without the backing of its linear companies. Notably, iROKO has also moved from being "a digital-only platform to both digital and linear," lite channel on Sky in 2016. iROKO was in the midst of this launch when I interviewed Jessica Hope, who emphasized that

With the launch of iROKO on Sky I think the company does see a future on [linear] TV.... With iROKO.tv as a streaming platform we might be missing out on a huge audience not going online for their content. You need to think about all of your audiences. ${ }^{71}$

It is notable in this respect that Kwesé, too, calls itself a "converged media company with pan-African businesses in Pay TV, Free-to-Air TV, and Digital." ${ }^{72}$ In the final analysis, then, Afrostream's failure as a streaming-only platform (particularly as it entered Africa-based markets), iROKO's move to satellite, Showmax's incorporation into a media unit alongside linear television, and Kwesé's range of nonlinear as well as linear platforms clearly signal that VOD alone will not currently succeed in Africa without a multipronged approach that also focuses on more traditional forms of television.

\section{Conclusion: Toward Connectivity}

Black Panther's uplifting story of T'Challa returning home from the United States to the fictional African country of Wakanda and thereby reuniting the African diaspora with Africans on the continent has inspired many viewers across the world and has also been a point of controversy. The research presented here reveals that it is easy to romanticize Africa-based and diasporan African connections but more difficult to establish these connections in practice. There is a stark difference between the content and viewing experiences that people have access to outside Africa through SVODs, and the "supersmall" screen viewing and shortform content that characterizes internet television for the majority of Africans on the continent. However, while such "mobile television"-watched individually, on a "supersmall" screen, while on the move-is being touted as the television of the young generation in Africa ${ }^{73}$ Henry Jenkins reminds us that new media rarely entirely eclipses old media. ${ }^{74}$ The "particular kind of sociality" that television viewing has historically created in African contexts, via "shared engagement with an audiovisual text in a domestic or frequently shared work space," or indeed in one of the thousands of makeshift video halls around the continent which beam sport and movies to collective audiences through a television set, is unlikely to disappear any time soon. ${ }^{75}$ The companies leading creative innovation in the African internet television space have recognized this and are prioritizing region-crossing connections and partnerships that will allow them to reach both nonlinear and linear audiences-at least until internet connectivity and access to data on the African continent improve to the extent that the SVOD model offers a viable business model. 


\section{Acknowledgments}

I am very grateful to everyone who granted me interviews (see list of interviews) and for the generous support and help of these colleagues: Jorge Cohen, Ugo Ben Ebelebe, Winston Mano, Ikechukwu Obiaya, and Wendy Willems. Thank you, also, to the two anonymous reviewers of this article who provided invaluable feedback and advice.

${ }^{1}$ Lindiwe Dovey is Reader in Screen Arts and Industries at SOAS University of London and Chair of the SOAS Centre for Media and Film Studies. She is also a filmmaker, film festival founder/director, and film curator. She has published widely on film and screen media, and her most recent book is Curating Africa in the Age of Film Festivals (Palgrave, 2015).

${ }^{2}$ Chimamanda Adichie Ngozi, "The Danger of a Single Story," TEDGlobal, July 2009, https://www.ted.com/talks/chimamanda_adichie_the_danger_of_a_single_story.

${ }^{3}$ See, in particular, Paul Zeleza and Cassandra Veney, eds., Leisure in Urban Africa (Trenton: Africa World Press, 2003).

${ }^{4}$ Dambisa Moyo, Dead Aid: Why Aid Is Not Working and How There Is Another Way for Africa (London: Allen Lane, 2009).

${ }^{5}$ Jonathan Haynes and Onokoome Okome, "Evolving Popular Media: Nigerian Video Films," Research in African Literatures 29 (3, 1998): 106-28.

${ }^{6}$ See, in particular, Jon Harald Sande Lie, Developmentality: An Ethnography of the World Bank-Uganda Partnership (New York: Berghahn Books, 2015).

${ }^{7}$ Recent books that focus on Nollywood's entertainment value include the following: Jonathan Haynes, Nollywood: The Creation of Nigerian Film Genres (Chicago: University of Chicago Press, 2016); and Jade Miller, Nollywood Central (New York: Palgrave, 2016).

${ }^{8}$ Charles Okigbo, "Africa," in Television: An International History, ed. Anthony Smith (Oxford: Oxford University Press, 1998), 236-46.

${ }^{9}$ Okigbo, "Africa," 238.

${ }^{10}$ Ibid.

${ }^{11}$ Moradewun Adejunmobi, "African Film's Televisual Turn," Cinema Journal 54 (2, 2015), 120-25.

${ }^{12}$ Ibid.

${ }^{13}$ Hence my focus on "Africa" and "Africans" as a whole; I do not intend to homogenize the continent, but I am rather responding here to the way that these companies frame themselves.

${ }^{14}$ See, however, Ugo Ben Ebelebe, "Reinventing Nollywood: The Impact of Online Funding and Distribution on Nigerian Cinema," Convergence: The International Journal of Research into New Media Technologies, published electronically, October 23, 2017, doi:10.1177/1354856517735792; Miller, Nollywood Central; Herman Wasserman, "The Ramifications of Media Globalization in the Global South for the Study of Media," Media Industries 1 (2, 2014).

${ }^{15}$ For example, Ikechukwu Obiaya, "Nollywood on the Internet: A Preliminary Analysis of an Online Nigerian Video-Film Audience," Journal of African Media Studies 2 (3, 2010): 321-38. 
${ }^{16}$ See, in particular, the articles in Journal of African Media Studies.

${ }^{17}$ For example, Ramon Lobato, "Rethinking International TV Flows Research in the Age of Netflix," Television E New Media 19 (3, May 2017): 241-56; Amanda Lotz, Portals: A Treatise on Internet-Distributed Television (Ann Arbor: University of Michigan Press, 2017).

${ }^{18}$ It is well known that Naspers, who owns Showmax, benefitted from being a white, Afrikaner-run company during apartheid in South Africa; see Martin Ndlela, "TV Formats in Anglophone Africa: The Hegemonic Role of South Africa in the TV Format Value Chain," International Journal of Digital Television 8 (1, 2017): 47-64. This history has been the source of a great deal of conflict and debate recently in the South African media scene; see Charles Blignaut, "The Pay TV Wars," Channel 24, December 24, 2017, https://www.channel24.co.za/TV/News/the-pay-tvwars-20171223.

${ }^{19}$ Lotz, Portals, loc. 195.

${ }^{20}$ Ramon Lobato, "Introduction: The New Video Geography," in Geoblocking and Global Video Culture, ed. Ramon Lobato and James Meese (Amsterdam: Institute of Network Cultures, 2015), 10-24.

${ }^{21}$ For example, Lobato, "Rethinking"; Lotz, Portals; Stuart Cunningham and Jon Silver, Screen Distribution and the New King Kongs of the Online World (Basingstoke: Palgrave Macmillan, 2013).

${ }^{22}$ Chris Savides, Email interview, January 19, 2018.

${ }^{23}$ Bob van Dijk, Skype interview, September 1, 2016.

${ }^{24}$ Lotz, Portals, loc. 210.

${ }^{25}$ African Business, "Going Digital: How Media in Africa Is Adapting to the Online Age," (446, November 2017), 14.

${ }^{26}$ Ibid.

${ }^{27}$ Ibid.

${ }^{28}$ See, for example, Chuck Tryon, On-Demand Culture: Digital Delivery and the Future of Movies (New Brunswick: Rutgers University Press, 2013).

${ }^{29}$ Alessandro Jedlowski, "Small Screen Cinema: Informality and Remediation in Nollywood," Television \& New Media 13 (5, 2012): 431-46.

${ }^{30}$ Glen Creeber, Small Screen Aesthetics: From TV to the Internet (London: Palgrave Macmillan, 2013).

${ }^{31}$ van Dijk, interview.

${ }^{32}$ Jessica Hope, Skype interview, September 13, 2016.

${ }^{33}$ Catherine Shu, "Nigeria-Based Online Entertainment Platform iROKO will Finance 'Nollywood' Films after Raising \$19M," Tech Crunch, January 25, 2016, https:// techcrunch.com/2016/01/25/iroko/.

${ }^{34}$ Bobola Oniwura, Skype interview, August 12, 2016.

${ }^{35}$ Tonjé Bakang, Skype interview, March 20, 2018.

${ }^{36}$ Ibid.

${ }^{37}$ See Sandvine, "2016 Global Internet Phenomena," Waterloo, Canada, 2016, https://www.sandvine.com/hubfs/downloads/archive/2016-global-internetphenomena-apac-mea.pdf and my list of interviews. 
${ }^{38}$ Jorge Cohen, MA Essay "Nollywood from the Streets of Lagos to Online Platforms," SOAS University of London, January 10, 2018.

${ }^{39}$ Russell Southwood, "Ad Boycott of YouTube Hits African Creators," Digital Content Africa, (86, May 2017), https://www.smartmonkeytv.com/channel/newsletters / ad_boycott_of_you_tube_hits_african_creators_and_channel_operators_as_ reven.

${ }^{40}$ Oniwura, interview.

${ }^{41}$ TechMoran, "iflix Launches Ad Supported Version to Support Its Business in Emerging Markets," May 2, 2018, https://techmoran.com/iflix-launches-adsupported-version-to-support-its-business-in-emerging-markets /.

42 Dorothy Ghettuba, Skype interview, May 16, 2018.

43 TechMoran, "iflix."

${ }^{44}$ Oniwura, interview.

${ }^{45}$ Ibid.

${ }^{46}$ Savides, interview.

${ }^{47}$ African Business, "Going Digital," 15.

${ }^{48}$ Henry Jenkins, Convergence Culture: Where Old and New Media Collide (NY: New York University Press, 2008), 4.

${ }^{49}$ Ravi Sundaram, Pirate Modernity (London: Routledge, 2010); Ramon Lobato, Shadow Economies of Cinema: Mapping Informal Film Distribution (London: British Film Institute, 2012).

${ }^{50}$ Russell Southwood, phone interview, January 26, 2018.

${ }^{51}$ African Business, "Going Digital," 19.

${ }^{52}$ Bakang, interview.

53 Ibid.

${ }^{54}$ Savides, interview.

${ }^{55}$ Ibid.

${ }^{56}$ Yolisa Phahle, Skype interview, September 13, 2016.

${ }^{57}$ Judy Kibinge, Email interview, January 25, 2018.

${ }^{58}$ TechMoran, "Showmax Inks Zuku Fiber Deal to Grow User Base," May 3, 2018, https://techmoran.com/showmax-inks-zuku-fiber-deal-to-grow-user-base/.

${ }^{59}$ Kibinge, interview.

${ }^{60}$ TechMoran, "Struggling Internet \& Pay TV Provider Zuku Sheds Hundreds of Jobs in Major Overhaul," May 16, 2017, https://techmoran.com/struggling-internet-paytv-provider-zuku-sheds-hundreds-jobs-major-business-model-overhaul/.

${ }^{61}$ Matthias Krings and Onookome Okome, eds., Global Nollywood (Indianapolis: Indiana University Press, 2013).

${ }^{62}$ Chidumga Izuzu, "Nollywood Channel to Launch on DSTV," Pulse.ng, October 18, 2016, http://www.pulse.ng/entertainment/movies/rok-studios-nollywoodchannel-to-launch-on-dstv-id5623434.html.

${ }^{63}$ Elsa Keslassy, "Canal Plus, iRoko Launch Mobile-First SVOD Service in FrenchSpeaking Africa," Variety, December 8, 2015, http://variety.com/2015/digital/ global/canal-plus-iroko-launch-mobile-first-svod-service-in-french-speakingafrica-1201656188/. 
${ }^{64}$ Tom Jackson, "Nigeria's iROKO Signs 'Multi-Million Euro Deal' with Canal+," Disrupt Africa, December 8, 2015, http://disrupt-africa.com/2015/12/nigerias-irokosigns-multi-million-euro-deal-with-canal/.

${ }^{65}$ Hope, interview.

${ }^{66}$ Ibid.

${ }^{67}$ Bakang, interview.

${ }^{68}$ Hope, interview.

${ }^{69}$ van Dijk, interview.

${ }^{70}$ African Business, "Going Digital," 19.

${ }^{71}$ Hope, interview.

${ }^{72}$ See https://www.kwese.com/aboutus.

${ }^{73}$ Russell Southwood, "Imageson Africa: La Revolution du Streaming en Afrique" (Presentation from Imageson, Casablanca, October 19-20, 2017), https://www. slideshare.net/newsbunny/la-revolution-du-streaming-en-afrique-81018065.

${ }^{74}$ Jenkins, Convergence.

${ }^{75}$ Adejunmobi, "African Film's Televisual Turn," 121.

\section{Bibliography}

Adejunmobi, Moradewun. "African Film's Televisual Turn." Cinema Journal 54, no. 2 (Winter 2015): 120-25.

Adeleke, Omolola. This is It. Produced by Doreen Media Africa, 2016-.

Creeber, Glen. Small Screen Aesthetics: From TV to the Internet. London: Palgrave Macmillan, 2013.

Cunningham, Stuart, and Jon Silver. Screen Distribution and the New King Kongs of the Online World. Basingstoke: Palgrave Macmillan, 2013.

Dayan, Daniel, and Elihu Katz. Media Events: The Live Broadcasting of History. Boston: Harvard University Press, 1994.

Dovey, Lindiwe. Curating Africa in the Age of Film Festivals. New York: Palgrave Macmillan, 2015.

Ebelebe, Ugo Ben. "Reinventing Nollywood: The Impact of Online Funding and Distribution on Nigerian Cinema." Convergence: The International Journal of Research into New Media Technologies. Published electronically October 23, 2017. doi:10.1177/1354856517735792.

Haynes, Jonathan. Nollywood: The Creation of Nigerian Film Genres. Chicago: University of Chicago Press, 2016.

Haynes, Jonathan, and Onokoome Okome, "Evolving Popular Media: Nigerian Video Films." Research in African Literatures 29, no. 3 (1998): 106-28.

Jedlowski, Alessandro. "Small Screen Cinema: Informality and Remediation in Nollywood." Television \& New Media 13, no. 5 (2012): 431-46. 
Jenkins, Henry. Convergence Culture: Where Old and New Media Collide. New York: New York University Press, 2008.

Krings, Matthias and Onookome Okome, eds. Global Nollywood. Indianapolis: Indiana University Press, 2013.

Lie, Jon Harald Sande. Developmentality: An Ethnography of the World Bank-Uganda Partnership. New York: Berghahn Books, 2015.

Lobato, Ramon and James Meese, eds. Geoblocking and Global Video Culture. Amsterdam: Institute of Network Cultures, 2015.

Lobato, Ramon. "Introduction: The New Video Geography." In Geoblocking and Global Video Culture, edited by Ramon Lobato and James Meese, 10-24. Amsterdam: Institute of Network Cultures, 2015.

Lobato, Ramon. "Rethinking International TV Flows Research in the Age of Netflix." Television E New Media 19, no. 3 (May 2017):241-56.Lobato, Ramon. Shadow Economies of Cinema: Mapping Informal Film Distribution. London: British Film Institute, 2012.

Lotz, Amanda. Portals: A Treatise on Internet-Distributed Television. Ann Arbor: University of Michigan Press, 2017.

Miller, Jade. Nollywood Central. New York: Palgrave, 2016.

Moyo, Dambisa. Dead Aid: Why Aid Is Not Working and How There Is Another Way for Africa. London: Allen Lane, 2009.

Mytton, Graham, and Ruth Teer-Tomaselli, and Andre-Jean Tudesq. "Transnational Television in Sub-Saharan Africa." In Transnational Television Worldwide: Towards a New Media Order, edited by Jean Chalaby, 96-127. London: I.B. Tauris, 2005.

Ndlela, Martin Nkosi. "TV Formats in Anglophone Africa: The Hegemonic Role of South Africa in the TV Format Value Chain." International Journal of Digital Television 8, no. 1 (2017): 47-64.

Obiaya, Ikechukwu. "Nollywood on the Internet: A Preliminary Analysis of an Online Nigerian Video-Film Audience." Journal of African Media Studies 2, no. 3 (2010): 321-38.

Okigbo, Charles (1998). "Africa." In Television: An International History, edited by Anthony Smith, 236-46. Oxford: Oxford University Press.

Sundaram, Ravi. Pirate Modernity. London: Routledge, 2010.

Tryon, Chuck. On-Demand Culture: Digital Delivery and the Future of Movies. New Brunswick: Rutgers University Press, 2013.

Uricchio, William. "The Future of a Medium Once Known as Television." In The YouTube Reader, edited by Pelle Snickars and Patrick Vonderau, 24-39. Stockholm: National Library of Sweden, 2009.

Wasserman, Herman. "The Ramifications of Media Globalization in the Global South for the Study of Media," Media Industries 1, no. 2 (2014). 
Williams, Raymond. Television: Technology and Cultural Form. Hanover: Wesleyan University Press, 1992.

Zeleza, Paul and Cassandra Veney, eds. Leisure in Urban Africa. Trenton: Africa World Press, 2003.

\section{List of Interviews}

Bakang, Tonjé. Skype interview. March 20, 2018.

Chiesa, Enrico. Email interview. April 25, 2014.

Cieplak, Piotr. Email interview. January 22, 2018.

Cohen, Jorge. Email interview. January 22, 2018.

Dado, Bayo. Email interview. August 30, 2016.

Fernandez, Estrella Sendra. Email interview. January 10, 2018.

Ghettuba, Dorothy. Skype interview. May 16, 2018.

Hope, Jessica. Skype interview. September 13, 2016.

Kibinge, Judy. Email interview. January 25, 2018.

Lora-Mungai, Marie. Email interview. April 23, 2014.

Oniwura, Bobola. Skype interview. August 12, 2016.

Phahle, Yolisa. Skype interview. September 13, 2016.

Savides, Chris. Email interview. January 19, 2018.

Southwood, Russell. Phone interview. January 26, 2018.

Thomas, Michael. Email interview. January 11, 2018.

Van Dijk, Bob. Skype interview. September 1, 2016. 